University of Nebraska - Lincoln

DigitalCommons@University of Nebraska - Lincoln

Publications from USDA-ARS / UNL Faculty

U.S. Department of Agriculture: Agricultural

Research Service, Lincoln, Nebraska

September 1998

\title{
Residual Effects of Crop Residues on Grain Production and Selected Soil Properties
}

James F. Power

University of Nebraska-Lincoln

Paul Koerner

University of Nebraska-Lincoln, pkoerner1@unl.edu

John W. Doran

University of Nebraska-Lincoln, jdoran1@unl.edu

Wallace Wilhelm

University of Nebraska-Lincoln, wwilhelm1@unl.edu

Follow this and additional works at: https://digitalcommons.unl.edu/usdaarsfacpub

Part of the Agricultural Science Commons

Power, James F.; Koerner, Paul; Doran, John W.; and Wilhelm, Wallace, "Residual Effects of Crop Residues on Grain Production and Selected Soil Properties" (1998). Publications from USDA-ARS / UNL Faculty. 89. https://digitalcommons.unl.edu/usdaarsfacpub/89

This Article is brought to you for free and open access by the U.S. Department of Agriculture: Agricultural Research Service, Lincoln, Nebraska at DigitalCommons@University of Nebraska - Lincoln. It has been accepted for inclusion in Publications from USDA-ARS / UNL Faculty by an authorized administrator of DigitalCommons@University of Nebraska - Lincoln. 


\title{
Residual Effects of Crop Residues on Grain Production and Selected Soil Properties
}

\author{
J. F. Power, ${ }^{*}$ P. T. Koerner, J. W. Doran, and W. W. Wilhelm
}

\begin{abstract}
Returning crop residue improves water conservation and storage, nutrient availability, and crop yields. We have little knowledge, however, of the residual impacts of crop residues on soil properties and crop production. We hypothesized that residual impacts of crop residues vary with the amount of residues used. A 10-yr study near Lincoln, NE, evaluated the residual effects of an earlier 8-yr study of various crop residue amounts on crop growth and selected soil properties. From 1978 through 1985, crop residues were returned at $0,50,100$, and $150 \%$ of the quantity produced by the previous crop (averaging 0 to $\approx 6 \mathrm{Mg} \mathrm{ha}^{-1} \mathrm{yr}^{-1}$ ). Continuous corn (Zea mays $\mathrm{L}$.) was produced 1986 through 1995 on these plots, except sorghum [Sorghum bicolor (L.) Moench] was substituted in several years. To study management effects on residual responses, plots were subdivided with or without tillage, $N$ fertilizer $\left(60 \mathrm{~kg} \mathrm{~N} \mathrm{ha}^{-1}\right)$, and hairy vetch (Vicia villosa L.) cover crop. Residual effects of the $150 \%$ residue amount increased grain production $16 \%$ compared with the $0 \%$ amount (4900 vs. $4250 \mathrm{~kg} \mathrm{ha}^{-1}$, respectively), and were not affected by time or other management practices. Increasing previous residue amount did enhance soil $N$ availability (from 73.0 to $82.3 \mathrm{~kg}$ autoclavemineralizable $N \mathrm{ha}^{-1}$ ) and Bray soil $P\left(16.7\right.$ to $\left.20.3 \mathrm{~kg} \mathrm{ka}^{-1}\right)$. These results are among the first to show that residual effects of crop residue are prolonged (half-life of $\approx 10 \mathrm{yr}$ ) and probably result from changes in soil properties that enhance soil nutrient availability.
\end{abstract}

$\mathrm{R}$ ESULTS FROM NUMEROUS STUDIES have shown that various amounts of crop residues affect soil properties and crop yields (Black, 1973; Larson et al., 1972). Usually those studies showed that returning increased amounts of crop residues to the soil increased soil organic matter content, microbial activity, nutrient availability, water infiltration and storage, and crop yields (Unger and McCalla, 1980; Fribourg and Bartholomew, 1956; Prasad and Power, 1991). Effects of crop residue amount were sometimes modified by other management practices such as type of tillage, fertilization, and use of cover crops (Maskina et al., 1993).

Understanding the effects of crop residues on soil properties and crop yields may be of greater importance

USDA-ARS, 119 Keim Hall, Univ. of Nebraska, Lincoln, NE 68583 0934. Received 6 Jan. 1997. *Corresponding author (jp32349@ navix.net)

Published in Soil Sci. Soc. Am. J. 62:1393-1397 (1998). in the future because of interest in using crop residues for production of paper products and ethanol. This is in addition to the conventional use of crop residues for fodder and bedding. Unfortunately, we presently have little information to evaluate the long-term impact of returning crop residues on soil productivity. We presently do not know the magnitude or duration of the effects of crop residue management practices on soil properties and crop production after we cease to use these practices. Therefore, we conducted an experiment to evaluate the duration and magnitude of the residual effects of various amounts of crop residues on soil properties and crop yields after we ceased returning crop residues in various amounts.

This experiment involved production of corn (sorghum in years when planting was delayed) using $\mathrm{N}$ fertilizers and no-till practices, to be consistent with practices used in earlier experiments (see below). It is conceivable that the management practices used for crop production could alter the type of response we obtained to the residual effects of using various crop residue amounts. Therefore, a second objective of this experiment was to determine how residual effects of previous crop residue amounts were impacted by tillage method, $\mathrm{N}$ availability, and use of winter cover crops.

\section{METHODS}

This research was conducted near Lincoln, NE, on a CreteButler silty clay loam (fine, montmorillonitic, mesic Pachic Arguistoll-Abruptic Agriaquoll) having a 1 to $2 \%$ slope. In establishing the previous variable residue amounts used in this project, two experiments were earlier conducted and completed on these plots. The first experiment was conducted in 1978,1979 , and 1980, when a no-till rotation of corn, sorghum, and soybean [Glycine max (L.) Merr.] was used to study how the quantity of crop residues on the soil surface $(0,50,100$, or $150 \%$ of the quantity produced by the previous crop) affected soil properties and crop yields (Doran et al., 1984). Corn and sorghum received $70 \mathrm{~kg} \mathrm{Nha}^{-1}$ and soybean received no fertilizer.

The second experiment was initiated after harvesting in 1980 , at which time crops were no longer rotated and the sorghum treatment was omitted. In this experiment we continued, on the same plots, the treatments of $0,50,100$, and $150 \%$ of the quantity of crop residue produced by the previous crop. 
Continuous corn and continuous soybean were grown in two separate blocks, produced without tillage (no-till) and with both crops receiving $45 \mathrm{~kg} \mathrm{~N}^{-1}$ annually (Wilhelm et al., 1986; Power et al., 1986). These procedures were followed through the 1985 crop, after which time the variable amount treatments were discontinued.

To meet our second objective of evaluating the effects of tillage, $\mathrm{N}$ fertilization, and cover crops on the residual effects of crop residue amounts, a split-plot technique was used. In 1986, plots of two replicates from each of the two crop blocks used in the second experiment at this site (conducted 19811985) were left as no-till and plots of another two replicates were disked. Each of these 36.4 by $36.4 \mathrm{~m}$ tillage plots for each of the former residue amounts was then split into four 9.1 by $9.1 \mathrm{~m}$ subplots, giving a total of 128 plots for the experiment. Treatments for these subplots were a factorial combination of 0 and $60 \mathrm{~kg} \mathrm{~N} \mathrm{ha}^{-1}$ as $\mathrm{NH}_{4} \mathrm{NO}_{3}$, with and without a hairy vetch (cv. Madison) cover crop. The experimental setup and procedures were described in more detail in Maskina et al. (1993).

Grain from corn or sorghum and stover yields were determined each year since 1985 by hand harvesting from a $5.0-\mathrm{m}^{2}$ area of each subplot. Grain and cob were dried and shelled, and grain water content was determined. Grain yield was adjusted to $0.155 \mathrm{~kg} \mathrm{H}_{2} \mathrm{O} \mathrm{kg}^{-1}$ for corn and $0.135 \mathrm{~kg} \mathrm{H}_{2} \mathrm{O} \mathrm{kg}^{-1}$ for sorghum. Stover in the sampling area was cut at the soil surface, weighed, and chopped into $2-\mathrm{cm}$ pieces. Subsamples were collected for water and total $\mathrm{N}$ analyses. Grain and stover were analyzed for total $\mathrm{N}$ as described by Schuman et al. (1973). Hairy vetch seed was surface broadcast in standing corn at $30 \mathrm{~kg}$ seed ha ${ }^{-1}$ about 1 September each year. Cover crops were disked into the soil a few days before corn planting on tilled plots, and were killed with 2,4-D amine (amine salt of 2,4-dichlorophenoxy acetic acid) and dicamba (2-methoxy3-6-dichlorobenzoic acid) for no-till plots. Hairy vetch was sampled from $2.0-\mathrm{m}^{2}$ areas in each subplot just prior to disking or spraying, weighed, and analyzed for water and $\mathrm{N}$ by the same procedure used for grain and stover samples.

Soils were sampled several times by depth increments to $30 \mathrm{~cm}$, collecting four to six 2-cm-diameter cores per subplot. These samples were analyzed for bulk density, organic $\mathrm{C}$, total $\mathrm{N}$, microbial biomass, potentially mineralizable $\mathrm{N}, \mathrm{pH}$, and $\mathrm{NO}_{3}-$ and $\mathrm{NH}_{4}-\mathrm{N}$ content using adaptations of standard procedures outlined in Page et al. (1982). Biological and chemical $\mathrm{N}$ availability indices were estimated using procedures outlined by Keeney (1982, p. 716) for anaerobic incubation and autoclaving. Until 1991, access tubes were inserted into selected plots and soil water content to $120 \mathrm{~cm}$ was monitored by neutron attenuation. Soils were also sampled to $120 \mathrm{~cm}$ in several years for $\mathrm{NO}_{3}-$ and $\mathrm{NH}_{4}-\mathrm{N}$ content.

Data were analyzed using analyses of variance. Least significant differences at $P=0.10$ were used for interpretation, except where stated otherwise.

\section{RESULTS}

Results from the first experiment conducted at this site (1978-1980) were summarized by Doran et al. (1984). Generally as quantity of crop residue increased, soil temperature decreased, soil water storage increased, and crop yields (both grain and stover) increased. An exception to the crop yield response was sorghum, which had a reduced stand at greater residue amounts (planting equipment available at that time had problems handling large amounts of surface residues).

Results of the second experiment (1980-1985) were
Table 1. Corn grain yields $\dagger$ as affected by residual effects of previous crop residue amounts from 0 to $150 \%$ of residue weight produced by previous crop.

\begin{tabular}{|c|c|c|c|c|}
\hline \multirow[b]{2}{*}{ Year } & \multicolumn{4}{|c|}{ Grain yield } \\
\hline & $0 \%$ & $50 \%$ & $100 \%$ & $150 \%$ \\
\hline & \multicolumn{4}{|c|}{$\mathbf{k g ~ h \mathbf { a } ^ { - 1 }}$} \\
\hline 1986 & 7140 & 7220 & 7780 & 7490 \\
\hline 1987 & 5650 & 5630 & 5360 & $\mathbf{5 8 3 0}$ \\
\hline 1988 & 3520 & 3640 & 3400 & 4550 \\
\hline 1989丮 & 2940 & 3610 & 3710 & 3400 \\
\hline 1990 & 4720 & 5630 & 5080 & 5440 \\
\hline 1991‡ & 2440 & 2520 & 3180 & 3130 \\
\hline 1992 & 3200 & 3300 & 3600 & 3860 \\
\hline 1993 & 4310 & 4890 & 4140 & 5540 \\
\hline 1994 & 5910 & 6420 & 5760 & 6700 \\
\hline 1995 & 2440 & 2910 & 2680 & 3080 \\
\hline Average & 4250 & 4580 & 4470 & 4900 \\
\hline
\end{tabular}

$\uparrow$ Average for no-till, with $60 \mathrm{~kg}$ fertilizer $\mathrm{N} \mathrm{ha}{ }^{-1}$ and no cover crop.

$¥$ Grain sorghum substituted for corn because of late planting.

presented by Wilhelm et al. (1986) and Power et al. (1986). Results of this project again showed direct positive correlations between amount of stover left on the soil surface and grain and stover yields for both corn and soybean. Uptake of both soil and fertilizer $\mathrm{N}$ increased as crop residue amount increased.

During the first 3 yr of the present study $(1986,1987$, and 1988), ${ }^{15} \mathrm{~N}$-depleted $\mathrm{NH}_{4} \mathrm{NO}_{3}$ fertilizers were used to study soil and fertilizer $\mathrm{N}$ availability. Results (Maskina et al., 1993) showed that residual effects of crop residues and use of cover crops increased soil $\mathrm{N}$ availability and $\mathrm{N}$ uptake by corn. Residual effects of the greatest compared with the least previous crop residue amounts increased corn grain and stover production 17 and $25 \%$, respectively. Likewise differences between greatest and least residual crop residue amounts for organic $\mathrm{C}$, total $\mathrm{N}$, and $\mathrm{NO}_{3}-\mathrm{N}$ in the upper $30 \mathrm{~cm}$ of soil were 10,12 , and $66 \%$, respectively.

Previous to 1986, all data reported in the above studies were from plots that had received $\mathrm{N}$ fertilizer, that were not tilled, and on which a cover crop was not grown. Crop grain yields for these same treatments for 1986 through 1995 are given in Table 1 . The residual effects of the previous crop residue amounts (1978$1985)$ on crop yields were similar to those reported earlier by Maskina et al. (1993) in that crop yields generally increased as previous crop residue amounts increased. The $16 \%$ greater grain yields for the residual effects of the $150 \%$ crop residue amounts over the $0 \%$ amount compares favorably with the $17 \%$ response recorded by Maskina et al. (1993) during the first $3 \mathrm{yr}$ of the experiment. This indicates that the residual response to previous treatment had not diminished with time. This point is further illustrated in Fig. 1, where the ratio of grain yield for these two treatments $(0$ and $150 \%$ treatments) is shown for each year, 1986 through 1995 (values shown are averages for all treatments studied, not just the no-till, N-fertilized plots without cover crops). Data in this figure show that grain yield responses varied among years from about 10 to $25 \%$, with no apparent time trend. Thus it appears that these 


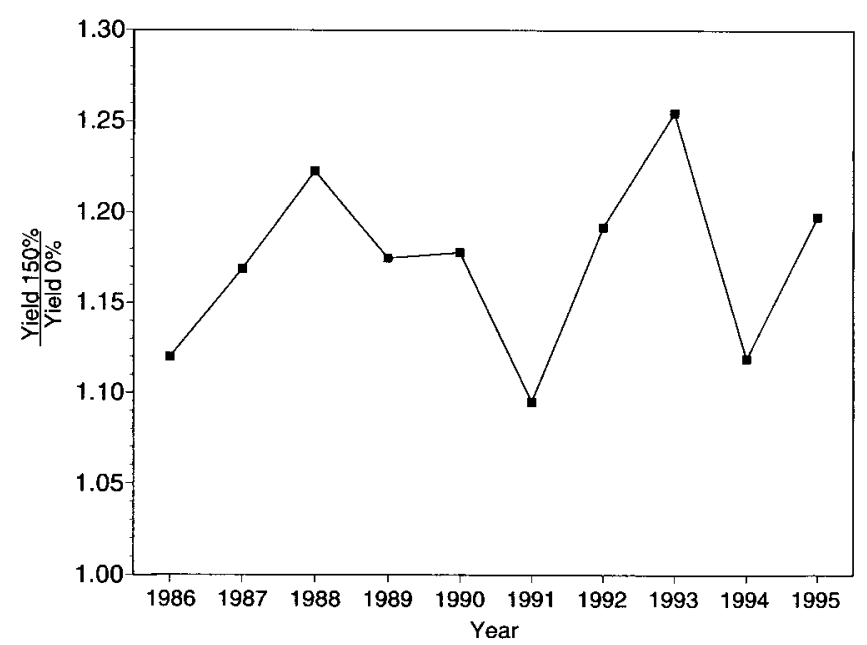

Fig. 1. Ratio of grain yields for $150 \%$ compared with $0 \%$ previous residue treatment amounts, 1986 through 1995.

residual effects of previous crop residue amounts have a prolonged impact on grain yields.

As stated above, a second objective of this experiment was to determine if these residual effects of earlier crop residue amounts were altered when other crop production practices were used. Consequently 10 -yr average grain yields are given in Table 2 for the effects of tillage, $\mathrm{N}$ fertilization, and cover crops at each of the four previous crop residue amounts. Tillage practices had no significant effects on yields, while the use of $\mathrm{N}$ fertilizer significantly increased average grain yields. Although cover crops had no significant effects on grain yields, the interaction between $\mathrm{N}$ fertilization and cover crop was significant. There was a greater crop yield response to $\mathbf{N}$ fertilization without than with a cover crop. This presumably occurred because the cover crop was able to provide part of the $\mathrm{N}$ needed by the grain crop.

No interactions were measured between tillage, $\mathrm{N}$ fertilization, or cover crops with previous crop residue amounts. This suggests that the prolonged residual ef- fects on corn yields of previous crop residue amounts for the no-till, no-cover-crop, N-fertilized treatment observed in Table 1 were likewise observed for all other management combinations. Therefore it seems that this residual effect of crop residues on grain yield was independent of soil and crop management practices.

In an attempt to determine the reason for these prolonged residual effects on crop yields, soils were sampled and analyzed on several dates to monitor a number of soil properties. Soil water data, collected for the first 7 yr after the variable-residue-amount treatment had ceased, showed no consistent treatment effects from the previous crop residue amounts, thereby essentially ruling out differential water conservation as being a causative factor of the residual effects on crop yields (data not shown). Results of analysis of soil samples collected from the 0- to 30-cm depth in April 1986 and the 0 - to $7.5-\mathrm{cm}$ depth in October 1987 were given in Maskina et al. (1993). These results showed that the residual effects of increasing the previous variable crop residue amounts had significantly increased soil organic matter, total $\mathrm{N}$, and $\mathrm{NO}_{3}-\mathrm{N}$, while reducing bulk density (upper $7.5 \mathrm{~cm}$ of soil only). There was no significant effect on microbial biomass.

Similar results were observed for soil samples collected in May 1992 (Table 3). Soil organic matter (15 $\mathrm{cm}$ ) and available soil P (Bray) $(30 \mathrm{~cm})$ generally increased with residual effects of previous crop residue amount to the $30-\mathrm{cm}$ soil depth. Previous crop residue treatments had little or no effect on soil $\mathrm{pH}$, soil $\mathrm{NO}_{3}-\mathrm{N}$, or soil $\mathrm{NH}_{4}-\mathrm{N}$ concentrations. Analysis of soil samples collected to the $150-\mathrm{cm}$ depth in May 1992 showed that, below $60 \mathrm{~cm}$, previous residue treatments had no significant effects on the soil properties measured (data not shown).

Additional soil samples were collected from the 0- to 75-mm soil depth in April 1994, and analyzed for bulk density, $\mathrm{NO}_{3}-$ and $\mathrm{NH}_{4}-\mathrm{N}$ concentrations, and mineralizable $\mathrm{N}$ content by both the autoclave and anaerobic

Table 2. Average (10-yr) corn $\dagger$ grain yields for previous crop residue amounts from 0 to $150 \%$ as affected by tillage, $\mathrm{N}$ fertilization, and cover crop.

\begin{tabular}{|c|c|c|c|c|c|c|}
\hline Tillage & Fertilizer & $\begin{array}{c}\text { Cover } \\
\text { crop }\end{array}$ & $0 \%$ & $\mathbf{5 0} \%$ & $100 \%$ & $150 \%$ \\
\hline & & & & 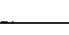 & 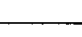 & 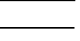 \\
\hline \multirow[t]{4}{*}{ Without } & Without & Without & 3730 & 3870 & 4010 & 4950 \\
\hline & Without & With & 3840 & 4240 & 4500 & 4820 \\
\hline & With & Without & 5440 & 5500 & 5510 & 5960 \\
\hline & With & With & 5340 & 5530 & 4960 & 5430 \\
\hline \multirow[t]{4}{*}{ With } & Without & Without & 3890 & 4050 & 4430 & 4790 \\
\hline & Without & With & 4340 & 4710 & 4560 & 5030 \\
\hline & With & Without & $\mathbf{5 5 3 0}$ & 5600 & 5670 & 6060 \\
\hline & With & With & 4850 & 5420 & 5010 & 5860 \\
\hline
\end{tabular}

\begin{tabular}{ll}
\multicolumn{1}{c}{ Source } & Probability \\
Residue amount (R) & $\mathbf{0 . 0 0 0 1 *}$ \\
$\mathbf{T i l a g e}(\mathbf{T})$ & $\mathbf{0 . 6 3 3}$ \\
$\mathbf{R} \times \mathbf{T}$ & $\mathbf{0 . 9 8 7}$ \\
$\mathbf{N i t r o g e n}(\mathbf{N})$ & $\mathbf{0 . 0 0 1}$ \\
$\mathbf{R} \times \mathbf{N}$ & $\mathbf{0 . 1 2 7}$ \\
$\mathbf{T} \times \mathbf{N}$ & $\mathbf{0 . 2 5 9}$ \\
$\mathbf{R} \times \mathbf{T} \times \mathbf{N}$ & $\mathbf{0 . 4 0 8}$
\end{tabular}

Analysis of variance

* Significant at the 0.05 probability level.

\begin{tabular}{lc}
\multicolumn{1}{c}{ Source } & Probability \\
$\mathbf{C o v e r}$ Crop (C) & 0.678 \\
$\mathbf{R} \times \mathbf{C}$ & 0.338 \\
$\mathbf{T} \times \mathbf{C}$ & 0.954 \\
$\mathbf{R} \times \mathbf{T} \times \mathbf{C}$ & $\mathbf{0 . 6 1 3}$ \\
$\mathbf{N} \times \mathbf{C}$ & $0.001^{*}$ \\
$\mathbf{R} \times \mathbf{N} \times \mathbf{C}$ & $\mathbf{0 . 7 5 6}$ \\
$\mathbf{T} \times \mathbf{N} \times \mathbf{C}$ & $\mathbf{0 . 3 4 9}$ \\
$\mathbf{R} \times \mathbf{T} \times \mathbf{N} \times \mathbf{C}$ & $\mathbf{0 . 5 9 9}$
\end{tabular}


Table 3. Residual effects of various crop residue amounts on selected soil properties to 30-cm depth, May 1992.

\begin{tabular}{|c|c|c|c|c|c|c|}
\hline $\begin{array}{l}\text { Previous } \\
\text { residue } \\
\text { amount }\end{array}$ & Depth & $\begin{array}{l}\text { Organic } \\
\text { matter }\end{array}$ & pH & $\mathrm{NO}_{3}-\mathrm{N}$ & $\mathbf{N H}_{4}-\mathbf{N}$ & Bray $P$ \\
\hline$\%$ & mm & $\mathrm{g} \mathrm{kg}^{-1}$ & & - & $\mathbf{m g ~ k g ^ { - 1 }}$ & \\
\hline \multirow[t]{3}{*}{0} & $0-75$ & 24.1 & 6.5 & 1.3 & 3.2 & 16.7 \\
\hline & 75-150 & 23.7 & 6.5 & 2.0 & 2.6 & 15.8 \\
\hline & $150-300$ & 24.5 & 6.4 & 1.9 & 2.5 & 16.0 \\
\hline \multirow[t]{3}{*}{50} & 0-75 & 25.4 & 6.3 & 2.2 & 2.9 & 20.7 \\
\hline & $75-150$ & 24.9 & 6.3 & 2.1 & 2.8 & 21.2 \\
\hline & $150-300$ & 24.9 & 6.3 & 1.8 & 2.8 & 20.5 \\
\hline \multirow[t]{3}{*}{100} & $0-75$ & 26.0 & 6.4 & 1.6 & 3.1 & 16.9 \\
\hline & 75-100 & 26.0 & 6.4 & 2.0 & $\mathbf{3 . 3}$ & 16.7 \\
\hline & $150-300$ & 26.2 & 6.4 & 1.9 & 3.1 & 17.5 \\
\hline \multirow[t]{3}{*}{150} & $0-75$ & 26.6 & 6.2 & 2.5 & 2.7 & 20.3 \\
\hline & 75-100 & 26.6 & 6.3 & 1.6 & $\mathbf{3 . 3}$ & 21.2 \\
\hline & $150-300$ & 26.1 & 6.2 & 1.7 & 3.1 & 18.3 \\
\hline \multirow[t]{3}{*}{ LSD (0.10) } & $0-75$ & 2.4 & $\mathbf{N S} \dagger$ & NS & NS & 2.2 \\
\hline & $75-150$ & 2.3 & NS & NS & 0.5 & 2.5 \\
\hline & $150-300$ & NS & NS & NS & NS & 2.5 \\
\hline
\end{tabular}

$\dagger$ NS $=$ not significant at $P=0.10$.

incubation procedures (Table 4). The residual effects of previous residue amount had significant effects on only soil $\mathrm{NO}_{3}-\mathbf{N}$ and mineralizable $\mathbf{N}$ as measured by the autoclave method. Generally, values for these properties increased as previous residue amount increased. A notable exception was the $100 \%$ amount, for which these measurements (and for many other measurements made in this experiment) were often similar to those for the $0 \%$ amount. No reason for this discrepancy is apparent.

\section{DISCUSSION AND CONCLUSION}

While it is well known that increasing the quantity of crop residues returned to the soil affects many soil properties and generally improves soil quality, the residual effects of such treatment have not been well documented. In this study, these residual effects were followed for $10 \mathrm{yr}$ after the variable crop residue amount treatments were terminated. Results show that use of increased crop residue amounts for $8 \mathrm{yr}$ improved the growth of the next 10 crops, with no evidence of a decline in this response with time. These results suggest that this crop growth response was probably caused by changes in soil properties and soil nutrient availability.

Similar enhancement of crop growth from residual effects of various crop residue amounts has been observed in unpublished experiments at Lancaster, WI (D.L. Karlen, 1996, personal communication). This observation suggests that results observed here may be a general phenomenon associated with increased crop

Table 4. Effects of previous crop residue amount on soil bulk density, soil $\mathrm{NO}_{3}-$ and $\mathrm{NH}_{4}-\mathrm{N}$, and potentially mineralizable $\mathrm{N}$ in April 1994 (0-75-mm depth).

\begin{tabular}{|c|c|c|c|c|c|}
\hline \multirow{2}{*}{$\begin{array}{l}\text { Previous } \\
\text { residue } \\
\text { amount }\end{array}$} & \multirow{2}{*}{$\begin{array}{c}\text { Bulk } \\
\text { density }\end{array}$} & \multirow[b]{2}{*}{$\mathbf{N O} \mathbf{O}_{3}-\mathbf{N}$} & \multirow[b]{2}{*}{$\mathbf{N H}_{4}-\mathbf{N}$} & \multicolumn{2}{|c|}{ Mineralizable $\mathbf{N}$} \\
\hline & & & & Autoclave & Anaerobic \\
\hline$\%$ & $\mathbf{M g ~ m}^{-3}$ & & 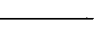 & $h a^{-1}$ & \\
\hline $\mathbf{0}$ & 1.51 & 6.6 & 0.2 & 73.0 & 37.2 \\
\hline 50 & 1.47 & 7.5 & 0.2 & $\mathbf{7 3 . 4}$ & 39.8 \\
\hline 100 & 1.44 & 6.0 & 0.2 & 71.3 & 37.2 \\
\hline 150 & 1.48 & 8.1 & 0.4 & 82.3 & 36.0 \\
\hline LSD (0.10) & $\mathbf{N S}+$ & 1.5 & NS & 7.5 & NS \\
\hline
\end{tabular}

$\dagger \mathrm{NS}=$ not significant at $P=\mathbf{0 . 1 0}$. residue amounts. If so, much further investigation is warranted to gain an understanding of the processes responsible and how we can best manage these processes.

In our investigations, while we documented the presence of these prolonged residual responses, we were not successful in definitely identifying factors responsible for this response. We have virtually eliminated enhanced water storage in soil for plots exhibiting these residual effects as being causative factors. This leads us to believe that the previous greater crop residue amounts improved some soil physical, chemical, or biological properties important in crop production. Mielke et al. (1984) and Doran $(1980,1987)$ have shown that crop residues, when applied to the soil, do improve certain soil physical and microbial properties. In our earlier study (Maskina et al., 1993), we showed that previous residue amounts did impact soil $\mathrm{N}$ availability and uptake. Data collected on mineralizable $\mathrm{N}$ by the autoclave method (Table 3) likewise suggest that enhanced $\mathbf{N}$ availability may contribute to the residual effects observed. However, this was not confirmed by the anaerobic incubation method. Whether the difference is real or is merely an artifact of the two methods used is unknown.

According to data presented by Maskina et al. (1993), the 8 yr of variable residue additions increased total soil $\mathrm{N}$ in the upper $30 \mathrm{~cm}$ for the $150 \%$ treatment by about $1.4 \mathrm{~g} \mathrm{~kg}^{-1}$ more than that of the $0 \%$ treatment. This would be $\approx 202 \mathrm{~kg}$ more $\mathrm{N} \mathrm{ha}^{-1}$ in soil of the $150 \%$ treatment than that of the $0 \%$ treatment. Again data in Maskina et al. (1993) show that total $\mathrm{N}$ in the harvested grain during the first $3 \mathrm{yr}$ of the residual study (years generally with higher yields than those that followed) averaged about $12 \mathrm{~kg} \mathrm{ha}^{-1} \mathrm{yr}^{-1}$ more for the $150 \%$ treatment than for the $0 \%$ treatment. Thus for the $10 \mathrm{yr}$ of the study, total soil $\mathrm{N}$ removed by crops for the $150 \%$ treatment would be about 100 to 120 $\mathrm{kg} \mathrm{ha}^{-1}$ greater than that for the $0 \%$ treatment. Thus, comparing the 0 to the $150 \%$ previous crop residue amounts, about half of the additional soil $\mathrm{N}$ that accumulated in 1978 through 1985 could have been accounted for by the $\mathrm{N}$ removed in the additional grain 
produced 1986 through 1995 . This change in soil $\mathrm{N}$ is generally too small to be detected by conventional soil $\mathrm{N}$ analyses. However, if the additional total soil $\mathrm{N}$ that resulted from the earlier high crop residue amounts was the primary cause for the residual effect of the previous crop residue treatments, these data suggest that the halflife of this effect is $\approx 10 \mathrm{yr}$. In addition to a relationship between soil $\mathrm{N}$ availability and crop responses to the previous various residue amounts, there was also a significant correlation between crop yield responses and soil $P$ availability. Thus it appears that increasing the quantity of crop residues returned to a soil may have a prolonged effect on increasing availability of nutrients other than $\mathrm{N}$.

In conclusion, the primary contribution of this study is documentation that residual effects of crop residues have a prolonged influence on soil properties and crop yield potential. This fact has seldom, if ever, been documented before. While data reported here do not directly identify the factor or factors responsible for the residual effects of crop residues, they do strongly imply that much of this residual response was probably due to differential soil nutrient availability, especially $\mathrm{N}$ availability (in high-yielding years, the $60 \mathrm{~kg} \mathrm{~N} \mathrm{ha}^{-1}$ fertilizer rate used was probably suboptimum for maximum corn yields). The previous use of higher crop residue amounts did increase total soil $\mathrm{N}$ content and there were changes in certain soil physical properties that enhanced microbial activity and the mineralization of soil N. Studies on soil $\mathrm{N}$ fractionation and the interactions of these $\mathrm{N}$ fractions with microbial processes are probably required to attain a more thorough understanding of the phenomena observed. Data collected in this study showed that neither tillage, $\mathrm{N}$ fertilization, nor cover crop practices had an appreciable impact on these residual effects of crop residue amount.

\section{REFERENCES}

Black, A.L. 1973. Soil property changes with crop residue management in a wheat-fallow rotation. Soil Sci. Soc. Am. Proc. 37:943-946.

Doran, J.W. 1980. Microbial changes associated with residue management with reduced tillage. Soil Sci. Soc. Am. J. 44:518-523.

Doran, J.W. 1987. Microbial biomass and mineralizable nitrogen distribution in no-tillage and plowed soils. Biol. Fertil. Soils 5:68-78.

Doran, J.W., W.W. Wilhelm, and J.F. Power. 1984. Crop residue removal and soil productivity with no-till corn, sorghum, and soybean. Soil Sci. Soc. Am. J. 48:640-645.

Fribourg, H.A., and U.V. Bartholomew. 1956. Availability of nitrogen from crop residues during the first and second year after application. Soil Sci. Soc. Am. Proc. 20:505-508.

Keeney, D.R. 1982. Nitrogen - Availability indices. p. 711-733. In A.L. Page et al. (ed.) Methods of soil analysis. Part 2. 2nd ed. Agron. Monogr. 9. ASA and SSSA, Madison, WI.

Larson, W.E., C.E. Clapp, W.H. Pierre, and Y.B. Morachan. 1972. Effects of increasing amounts of organic residues on continuous corn: II. Organic carbon, nitrogen, phosphorus, and sulfur. Agron. J. 64:204-208.

Maskina, M.S., J.F. Power, J.W. Doran, and W.W. Wilhelm. 1993. Residual effects of no-till crop residues on corn yield and nitrogen uptake. Soil Sci. Soc. Am. J. 57:1555-1560.

Mielke, L.N., J.W. Doran, and K.A. Richards. 1984. Physical environment near the surface of plowed and no-tilled surface soils. Soil Tillage Res. 7:355-366.

Page, A.L., R.H. Miller, and D.R. Keeney (ed.). 1982. Methods of soil analysis. Part 2. 2nd ed. Agron. Monogr. 9. ASA and SSSA, Madison, WI.

Power, J.F., J.W. Doran, and W.W. Wilhelm. 1986. Crop residue effects on soil environment and dryland maize and soybean production. Soil Tillage Res. 8:101-111.

Prasad, R., and J.F. Power. 1991. Crop residue management - literature review. Adv. Soil Sci. 15:205-251.

Schuman, G.E., M.A. Stanley, and D. Knudson. 1973. Automated total nitrogen analysis of soil and plant samples. Soil Sci. Soc. Am. Proc. 37:480-481.

Unger, P.W., and T.M. McCalla. 1980. Conservation tillage systems. Adv. Agron. 33:1-58.

Wilhelm, W.W., J.W. Doran, and J.F. Power. 1986. Corn and soybean yield response to crop residue management under no-tillage production systems. Agron. J. 78:184-189. 